\title{
Comparative study on proximate and antinutritional factors of dehulled and undehulled fermented Lyon bean (Mucuna cochinchinensis)
}

\author{
Olaleye, H.T., Oresanya, T.O. and Ogundipe, O.O. \\ Department of Food Technology, Yaba College of Technology, Yaba Lagos, Nigeria
}

\begin{abstract}
Article history:
Received: 9 April 2020

Received in revised form: 8

May 2020

Accepted: 15 May 2020

Available Online: 4 June 2020
\end{abstract}

\section{Keywords:}

Dehulled,

Un-dehulled,

Fermentation,

Anti-nutrients content,

Proximate analysis

DOI:

https://doi.org/10.26656/fr.2017.4(5).155

\begin{abstract}
The impact of fermentation times and temperatures on the proximate composition and anti -nutrient content of dehulled and un-dehulled Mucuna cochinchinensis flour were investigated. Dehulled and un-dehulled Lyon beans were subjected to fermentation at $30^{\circ}$ $\mathrm{C}$ and $45^{\circ} \mathrm{C}$ for 24,48 and $72 \mathrm{hrs}$ respectively and the fermented seeds were processed into flour. Results obtained revealed that the fermentation time/day had an effect on the proximate composition of the beans causing an appreciable increase in the crude protein (from 22.19 - 36.41\%) and fat content (from 4.94 - 10.79\%) of the fermented Mucuna beans samples when compared with results of the unfermented samples (22.19 and 4.94\%) while there was a decrease in carbohydrate (from 57.34 - 40.85\%) of the fermented beans. Anti-nutrients (oxalate, tannin and phytate) contents of the seeds decreased significantly (from 1.708-0.316 mg/g, 1.071-1.353\%, 1.868-0.515\%) as fermentation time and temperature also increased. This study has revealed that fermentation for $72 \mathrm{hrs}$ at $45^{\circ} \mathrm{C}$ was most effective in increasing the nutritional content of the beans while also reducing the anti-nutrient content to a minimum level.
\end{abstract}

\section{Introduction}

In different parts of the world today, legumes are some of the most necessary foods consumed. The seeds contain at least twice the amount of protein present in cereals and the profile of the essential amino acids shows that it is more adequate. These legumes range from those usually consumed such as cowpea, soybean and groundnut to the underutilized ones such as African yam bean, Lyon beans and Lima beans (Ndidi et al., 2014).

Lyon beans (Mucuna cochinchinensis), one of the many species of Mucuna in the family Leguminosae, is an underutilized tropical legume grown in many parts of the world. It is nutritionally comparable to other legumes such as soybeans because of their similar contents of protein, fat and other nutrients (Adebowale et al. 2005). It contains approximately $28.7 \%$ protein, $6.12 \%$ ether extract, $3.82 \%$ crude fibre, $3.97 \%$ ash, $50.3 \%$ nitrogen free extract and $4.42 \mathrm{kcal} / \mathrm{g}$ energy. It is used as a minor food crop in parts of Nigeria as well as Asia (Tuleun et al., 2008).

The need for cheap sources of protein for developing countries has led many individuals to research potentials of underutilized legumes to supply valuable nutrients of which Lyon beans are one but its utilization in food forms may be hindered as a result of the anti-nutritional factors present in the plant. These anti-nutritional factors have been reported to interfere with nutrient absorption and also cause a reduction in nutrient intake, digestion and utilization (Popova and Mihaylova, 2019). Consumption of food containing anti-nutritional factors may cause some specific symptoms in the human body such as nausea, rashes, bloating, and nutritional deficiencies among others (Essack et al., 2017).

In order to improve the nutritional content and reduce the anti-nutrient contents of Mucuna species, some common processing methods have been used such as soaking in portable water, heating in water, alkaline or acid solutions at elevated temperatures, germination, roasting, dehulling and fermentation (Esenwah et al., 2010).

Fermentation has proven over the years to be one of the most effective processing methods to practically limit anti-nutritional factors of legumes (Onwurafor et al., 2014; Bello and Udo, 2017; Iheke et al., 2017). The knowledge of the optimum temperature-time combination to achieve the fermentation of the beans will give a clear profile about how to eliminate antinutrients and increase the utilization of this underutilized crop. Therefore, this study was carried out to 
determine the optimum fermentation temperature-time combination than could effectively reduce or eliminate anti-nutritional factors in Mucuna cochinchinensis.

\section{Materials and methods}

\subsection{Fermentation and preparation of the seed flour}

Samples of Lyon beans were purchased from Iddo market, Yaba, Lagos, Nigeria. Lyon bean was sorted to discard damaged or immature seeds. The seeds were portioned in two parts. The first part was further portioned into two. One portion was milled whole, sieved using a $0.5 \mu \mathrm{m}$ mesh size, packaged in zip lock bags and stored at $4{ }^{\circ} \mathrm{C}$ until further analysis. The second portion was dehulled, milled, sieved using $0.5 \mu \mathrm{m}$, packaged in zip lock bags and stored at $4^{\circ} \mathrm{C}$ until further analysis. The second part was further divided into twelve portions; the first six portions used as un-dehulled and the second six were dehulled for the fermentation process (Table 1). The seeds were soaked separately in sterile water for $10 \mathrm{hrs}$, drained, and fermented in a perforated polyethylene bag at $30^{\circ} \mathrm{C}$ and $45^{\circ} \mathrm{C}$ for $24 \mathrm{hrs}$, $48 \mathrm{hrs}$ and $72 \mathrm{hrs}$ respectively. Fermentation was carried out in a Gallenkamp Incubator (INC200 Plus Series) and temperature range applicable to each sample was kept constant. The fermented seeds were dried in a cabinet dryer (D28, Nigeria) at $60^{\circ} \mathrm{C}$, milled, sieved using sieve with mesh size $0.5 \mu \mathrm{m}$, packaged in zip lock bags and stored at $4^{\circ} \mathrm{C}$ until further analysis. The unfermented beans were used as control samples (modified method of Udensi et al., 2006).

Table 1. Sample codes with fermentation time and temperature combinations

\begin{tabular}{cl}
\hline Sample codes & \multicolumn{1}{c}{ Treatment } \\
\hline WUMC $_{1}$ & Whole unfermented mucuna bean \\
DUFMC $_{2}$ & Dehulled unfermented mucuna bean \\
$\mathrm{UFMC}_{3}$ & Un-dehulled Fermented at $30^{\circ} \mathrm{C}$ for $24 \mathrm{hrs}$ \\
$\mathrm{UFMC}_{4}$ & Un-dehulled fermented at $30^{\circ} \mathrm{C}$ for $48 \mathrm{hrs}$ \\
$\mathrm{UFMC}_{5}$ & Un-dehulled Fermented at $30^{\circ} \mathrm{C}$ for $72 \mathrm{hrs}$ \\
$\mathrm{UFMC}_{6}$ & Un-dehulled Fermented at $45^{\circ} \mathrm{C}$ for $24 \mathrm{hrs}$ \\
$\mathrm{UFMC}$ & Un-dehulled fermented at $45^{\circ} \mathrm{C}$ for $48 \mathrm{hrs}$ \\
$\mathrm{UFMC}_{8}$ & Un-dehulled Fermented at $45^{\circ} \mathrm{C}$ for $72 \mathrm{hrs}$ \\
$\mathrm{DFMC}_{9}$ & Dehulled fermented at $30^{\circ} \mathrm{C}$ for $24 \mathrm{hrs}$ \\
$\mathrm{DFMC}_{10}$ & Dehulled fermented at $30^{\circ} \mathrm{C}$ for $48 \mathrm{hrs}$ \\
$\mathrm{DFMC}_{11}$ & Dehulled fermented at $30^{\circ} \mathrm{C}$ for $72 \mathrm{hrs}$ \\
$\mathrm{DFMC}_{12}$ & Dehulled fermented at $45^{\circ} \mathrm{C}$ for $24 \mathrm{hrs}$ \\
$\mathrm{DFMC}_{13}$ & Dehulled fermented at $45^{\circ} \mathrm{C}$ for $48 \mathrm{hrs}$ \\
$\mathrm{DFMC}_{14}$ & Dehulled fermented at $45^{\circ} \mathrm{C}$ for $72 \mathrm{hrs}$ \\
\hline
\end{tabular}

\subsection{Determination of proximate composition}

Proximate constituents (moisture, ash, crude fat, crude fibre, and protein) contents were assessed as per
AOAC (2005), and carbohydrates were determined by difference.

\subsection{Anti-nutritional content}

Selected anti-nutrients that were determined were phytic acid, oxalic acid and tannin contents. Phytic and Oxalic acid contents were determined using the AOAC (2005) procedure while the method described by Kirk and Sawyer (1998) was used to determine tannin content.

\subsection{Statistical analysis}

Data obtained were subjected to analysis of variance (ANOVA) using SPSS version 21.0 and the differences between significant mean values were evaluated at $p<$ 0.05 probability level using Duncan's Multiple Range Test.

\section{Result and discussion}

\subsection{Proximate composition}

The results of the proximate content of unfermented and fermented beans are presented in Table 2. Crude protein and carbohydrate have been attributed to be the major proximate constituents of legume samples. The protein content determined ranged between $19.97 \pm 0.08$ and $36.41 \pm 0.025$. The $36.41 \pm 0.25$ obtained from the sample (dehulled fermented at $30^{\circ} \mathrm{C}$ for $72 \mathrm{hrs}$ ) was higher than reports by other researchers of some other common legumes with a range of 18.5 to $21.9 \%$ (Costa et al., 2006; Mugendi et al., 2010). The protein content of Lyon bean was found to be within the range reported for cowpea at $29.3 \%$ (Tresina and Mohan, 2013). As a result of this high crude protein content of the samples investigated, it is expected that Lyon beans will be useful as an alternative protein source.

The moisture content of the Lyon beans ranged between $5.10 \pm 0.11$ and $10.62 \pm 0.23$ with dehulled fermented at temperature $45^{\circ} \mathrm{C}$ for $48 \mathrm{hrs}$ having the least and raw unfermented Lyon bean seeds having the highest. Percentage fat content determined ranged between $4.06 \pm 0.15$ and $10.44 \pm 0.69$ with dehulled fermented Lyon bean seed having the least and unfermented Lyon bean seed the highest. This observed rise in the fat content may be because of soaking the seeds for $10 \mathrm{hrs}$ which caused the breakdown of the protein-lipid or carbohydrate-lipid bonds which has been reported to give rise to easy fat extraction of legumes (Omafuvbe et al., 2004).

Crude fibre content of all sample ranged between $0.79 \pm 0.08$ to $4.83 \pm 0.21$ with the unfermented Lyon bean seed having the highest and dehulled fermented Lyon bean the least. The variation in the results observed in the dehulled fermented beans may be due to total 
Table 2. Proximate composition of the Lyon beans samples

\begin{tabular}{|c|c|c|c|c|c|c|}
\hline Sample & Moisture Content $(\%)$ & Protein $(\%)$ & Fat $(\%)$ & Crude Ash (\%) & Crude Fiber (\%) & Carbohydrate (\%) \\
\hline WUMC1 & $10.62 \pm 0.23^{\mathrm{a}}$ & $22.19 \pm 2.06^{\mathrm{b}}$ & $4.94 \pm 0.11^{\mathrm{d}}$ & $3.53 \pm 0.27^{\mathrm{c}}$ & $1.40 \pm 0.22^{\mathrm{e}}$ & $57.34 \pm 2.23^{\mathrm{ab}}$ \\
\hline DUFMC2 & $10.5 \pm 0.18^{b}$ & $26.66 \pm 0.30^{\mathrm{c}}$ & $8.66 \pm 0.26^{\mathrm{a}}$ & $5.10 \pm 0.05^{\mathrm{bc}}$ & $1.22 \pm 0.10^{\mathrm{d}}$ & $47.81 \pm 0.52^{\mathrm{e}}$ \\
\hline UFMC3 & $9.22 \pm 0.08^{c}$ & $22.43 \pm 0.52^{\mathrm{a}}$ & $10.09 \pm 0.05^{\mathrm{b}}$ & $4.39 \pm 0.09^{\mathrm{d}}$ & $3.91 \pm 0.04^{\mathrm{ac}}$ & $49.98 \pm 0.51^{\mathrm{b}}$ \\
\hline UFMC4 & $8.83 \pm 0.28^{\mathrm{ab}}$ & $24.84 \pm 0.26^{\mathrm{ab}}$ & $10.44 \pm 0.69^{\mathrm{c}}$ & $3.32 \pm 0.05^{\mathrm{cd}}$ & $2.16 \pm 0.08^{\mathrm{bc}}$ & $50.43 \pm 1.36^{\mathrm{ac}}$ \\
\hline UFMC5 & $8.76 \pm 0.30^{\mathrm{ac}}$ & $32.69 \pm 0.51^{\mathrm{bc}}$ & $7.56 \pm 0.13^{\mathrm{c}}$ & $5.29 \pm 0.07^{\mathrm{a}}$ & $3.20 \pm 0.16^{\mathrm{ae}}$ & $42.51 \pm 0.57^{\text {be }}$ \\
\hline UFMC6 & $7.83 \pm 0.21^{\text {be }}$ & $22.91 \pm 0.17^{\mathrm{d}}$ & $10.07 \pm 0.08^{\mathrm{ac}}$ & $3.78 \pm 0.05^{\mathrm{b}}$ & $2.67 \pm 0.08^{\mathrm{bd}}$ & $52.75 \pm 0.33^{\mathrm{d}}$ \\
\hline UFMC7 & $7.78 \pm 0.08^{\mathrm{bc}}$ & $22.10 \pm 0.05^{\mathrm{ac}}$ & $8.00 \pm 0.18^{\mathrm{bc}}$ & $3.07 \pm 0.08^{\mathrm{ab}}$ & $4.83 \pm 0.21^{\mathrm{a}}$ & $54.23 \pm 0.52^{\mathrm{c}}$ \\
\hline UFMC8 & $6.77 \pm 0.21^{\text {be }}$ & $35.52 \pm 0.84^{\text {ad }}$ & $7.49 \pm 0.34^{\text {ad }}$ & $3.10 \pm 0.04^{\text {cd }}$ & $4.33 \pm 0.09^{c}$ & $42.80 \pm 1.34^{\mathrm{ac}}$ \\
\hline DFMC9 & $8.05 \pm 0.25^{\mathrm{ae}}$ & $32.65 \pm 0.34^{\mathrm{bd}}$ & $4.06 \pm 0.15^{\mathrm{ab}}$ & $4.44 \pm 0.20^{\mathrm{ac}}$ & $0.91 \pm 0.03^{\mathrm{ce}}$ & $49.90 \pm 0.07^{\mathrm{bd}}$ \\
\hline DFMC10 & $9.22 \pm 0.26^{\mathrm{ae}}$ & $19.97 \pm 0.08^{\text {ae }}$ & $7.67 \pm 0.12^{\mathrm{bd}}$ & $3.42 \pm 0.06^{\mathrm{cd}}$ & $1.45 \pm 0.13^{\mathrm{de}}$ & $58.29 \pm 0.54^{\mathrm{de}}$ \\
\hline DFMC11 & $8.79 \pm 0.21^{\mathrm{d}}$ & $36.41 \pm 0.25^{\text {be }}$ & $8.33 \pm 0.45^{\text {ae }}$ & $4.85 \pm 0.23^{\mathrm{e}}$ & $0.79 \pm 0.13^{\mathrm{ce}}$ & $40.85 \pm 0.35^{\text {ac }}$ \\
\hline DFMC12 & $12.71 \pm 0.28^{\mathrm{ad}}$ & $29.12 \pm 0.47^{\mathrm{cd}}$ & $9.27 \pm 0.14^{\text {be }}$ & $4.76 \pm 0.18^{\mathrm{ae}}$ & $0.29 \pm 0.11^{\mathrm{ce}}$ & $43.86 \pm 1.17^{\text {ad }}$ \\
\hline DFMC13 & $5.10 \pm 0.11^{\mathrm{e}}$ & $24.69 \pm 0.21^{\text {ae }}$ & $5.66 \pm 0.14^{\mathrm{c}}$ & $3.35 \pm 0.21^{\text {be }}$ & $3.38 \pm 0.16^{\text {be }}$ & $57.82 \pm 0.83^{\mathrm{cd}}$ \\
\hline DFMC14 & $7.46 \pm 0.26^{\mathrm{bd}}$ & $31.47 \pm 0.23^{\mathrm{e}}$ & $10.79 \pm 0.31^{\mathrm{cd}}$ & $3.66 \pm 0.18^{\mathrm{ce}}$ & $0.90 \pm 0.08^{\mathrm{cd}}$ & $45.73 \pm 0.61^{\mathrm{a}}$ \\
\hline
\end{tabular}

Mean values with different letters in a column are significantly different at 95\% confidence level ( $\mathrm{p}$-value $<0.05$ ).

breakdown of the endosperm of the legume which normally houses the fibrous material of the beans. The crude fibre content in both fermented and unfermented samples was significantly different from the dehulled and fermented samples lower than unfermented samples.

Crude ash content of the investigated Lyon bean ranged between $3.07 \pm 0.08$ and $5.10 \pm 0.05$. Results were similar to reports in the literature for mucuna varieties/ species $(4.78-5.30 \%$ ) (Kala and Mohan, 2010). It was within the range $(3.4-4.0 \%)$ reported for beans but lower than values $(9.8 \% ; 10.4 \%)$ reported for chickpeas and peas (Costa et al., 2006; Tresina and Mohan, 2013). The carbohydrate content was found to range $40.85 \pm 0.35$ to $58.29 \pm 0.35$. Significant differences $(\mathrm{P}<0.05)$ were observed between the results of carbohydrate in the fermented and unfermented samples.

Results for dehulled Lyon bean seeds were observed to be higher than that of un-dehulled beans and this could be attributed to the effect of the soaking and dehulling processing methods which have been reported to improve the nutritional content of legumes (Oghbaei and Prakash, 2016).

\subsection{Anti-nutritional content}

Results of the anti-nutritional content of unfermented and fermented beans are presented in Table 3. The antinutrients content of the fermented beans flour was observed to be lower than that of the unfermented beans flour samples. Oxalate content ranged between $0.316 \pm 0.001 \mathrm{mg} / \mathrm{g}$ to $1.708 \pm 0.005 \mathrm{mg} / \mathrm{g}$ with dehulled fermented at $45^{\circ} \mathrm{C}$ for $48 \mathrm{hrs}$ having the least and the highest raw unfermented Lyon beans. There was no significant difference between undehulled fermented at $30^{\circ} \mathrm{C}$ for $24 \mathrm{hrs}$ and undehulled fermented at $45^{\circ} \mathrm{C}$ for 24 hrs $\left(\mathrm{UFMC}_{3}\right.$ and $\left.\mathrm{UFMC}_{6}\right)$ but there was a significant difference among the remaining samples.

Table 3. Result of the anti-nutrients of the Lyon beans samples

\begin{tabular}{|c|c|c|c|}
\hline Sample & mg/g Oxalate & \% Phytic acid & \%Tannin \\
\hline WUMC1 & $1.708 \pm 0.005^{\mathrm{a}}$ & $1.971 \pm 0.060^{\mathrm{e}}$ & $1.868 \pm 0.052^{\mathrm{b}}$ \\
\hline DUFMC2 & $1.548 \pm 0.005^{\mathrm{b}}$ & $1.787 \pm 0.054^{\mathrm{a}}$ & $1.814 \pm 0.050^{\mathrm{c}}$ \\
\hline UFMC3 & $1.426 \pm 0.004^{\mathrm{cd}}$ & $1.691 \pm 0.051^{\mathrm{e}}$ & $1.697 \pm 0.047^{\mathrm{d}}$ \\
\hline UFMC4 & $1.387 \pm 0.004^{\mathrm{c}}$ & $1.503 \pm 0.046^{\mathrm{b}}$ & $1.658 \pm 0.046^{\mathrm{a}}$ \\
\hline UFMC5 & $1.233 \pm 0.004^{\mathrm{ab}}$ & $1.490 \pm 0.045^{\text {be }}$ & $1.638 \pm 0.045^{\mathrm{de}}$ \\
\hline UFMC6 & $0.777 \pm 0.002^{\mathrm{cd}}$ & $1.456 \pm 0.044^{\mathrm{c}}$ & $1.550 \pm 0.043^{\mathrm{ab}}$ \\
\hline UFMC7 & $0.630 \pm 0.002^{\mathrm{ac}}$ & $1.701 \pm 0.052^{\mathrm{ab}}$ & $1.608 \pm 0.045^{\mathrm{bc}}$ \\
\hline UFMC8 & $0.546 \pm 0.002^{\text {be }}$ & $1.496 \pm 0.046^{\mathrm{bc}}$ & $1.388 \pm 0.038^{\mathrm{cd}}$ \\
\hline DFMC9 & $0.440 \pm 0.001^{\mathrm{bc}}$ & $1.435 \pm 0.044^{\mathrm{ac}}$ & $1.300 \pm 0.036^{\mathrm{ad}}$ \\
\hline DFMC10 & $0.424 \pm 0.001^{\mathrm{d}}$ & $1.408 \pm 0.043^{\mathrm{e}}$ & $1.280 \pm 0.035^{\mathrm{bd}}$ \\
\hline DFMC11 & $0.411 \pm 0.001^{\mathrm{ce}}$ & $1.399 \pm 0.043^{\mathrm{cd}}$ & $0.868 \pm 0.024^{\mathrm{e}}$ \\
\hline DFMC12 & $0.330 \pm 0.001^{\mathrm{ce}}$ & $1.385 \pm 0.042^{\mathrm{ae}}$ & $0.618 \pm 0.017^{\mathrm{ce}}$ \\
\hline DFMC13 & $0.316 \pm 0.001 \mathrm{e}$ & $1.378 \pm 0.042^{\mathrm{de}}$ & $0.579 \pm 0.016^{\mathrm{ae}}$ \\
\hline DFMC14 & $0.321 \pm 0.001^{\mathrm{de}}$ & $1.353 \pm 0.041^{\mathrm{e}}$ & $0.515 \pm 0.014^{\mathrm{ae}}$ \\
\hline
\end{tabular}

Mean values with different letters in a column are significantly different at $95 \%$ confidence level ( $p$-value $<0.05$ ).

The phytic acid content ranged between $1.971 \pm 0.060$ to $1.353 \pm 0.041 \%$ with dehulled fermented seeds having the least and the raw mucuna seed having the highest. The high phytate content $(1.353 \pm 0.041)$ of the dehulled fermented Lyon bean samples could be as a result of their high prevalence in the cotyledons. In legumes, phytates have been reported to bind multivalent cations thereby reducing the bioavailability of mineral elements present in foods. They were also known to form complexes with protein and starch, thereby inhibiting the enzymatic digestion of starch and protein (Oatway et al., 2001). 
The tannin content ranged from $1.868 \pm 0.052$ to $0.515 \pm 0.014$ with dehulled fermented mucuna seed at $45^{\circ} \mathrm{C}$ for $72 \mathrm{hrs}$ having the least and the raw Lyon bean seed having the highest. There was no significant difference between dehulled fermented muсuna bean at $45^{\circ} \mathrm{C}$ for $48 \mathrm{~h}$ and at $45^{\circ} \mathrm{C}$ for $72 \mathrm{hrs}$ but there is significant difference among all other samples.

As fermentation time increased, the anti-nutrients content reduced. The dehulled fermented Lyon beans flour samples were found to have lower values for antinutrients compared with the un-dehulled fermented Lyon beans flour samples. It has been reported that combining several pre-processing treatments such as soaking, dehulling, fermentation and milling, reduces anti-nutrient content in legumes. This also indicates that the antinutrients are more concentrated in the hull (Oghbaei and Prakash, 2016).

\section{Conclusion}

This research work has shown fermentation significantly increased the protein and fat contents while also reducing the anti-nutrients content of the flour. The optimal fermentation time and temperature for Lyon beans flour with good nutritional properties as well as reduced anti-nutrients content were at $45^{\circ} \mathrm{C}$ for $72 \mathrm{hrs}$. This study confirms dehulling and fermentation improved the nutritional quality of Lyon beans flour and this can enhance the utilization of the beans.

\section{References}

Adebowale, A.Y., Adeyemi, A.I. and Oshodi, A.A. (2005). Functional and physicochemical properties of flours of six Mucuna species. African Journal of Biotechnology, 4(12), 1461-1468

AOAC. (2005). Official methods of analysis of the Association of the Official Analytical Chemists. $17^{\text {th }}$ ed. Arlington, Virginia, USA: AOAC.

Bello, F.A. and Udo, V.T. (2017). Effect of Fermentation on the Nutritional, Anti-Nutritional and Functional Properties of Horse Eye Beans (Mucuna urens) Flour. Current Journal of Applied Science and Technology, 24(3), 1-7. https://doi.org/10.9734/ CJAST/2017/37311

Costa, G.E.A., Queiroz-Monici, K.S., Reis, S.M.P.M. and Oliveira, A.C. (2006). Chemical composition, dietary fibre and resistant starch contents of raw and cooked pea, common bean, chickpea and lentil legumes. Journal of Food Biochemistry, 94(3), 327330. https://doi.org/10.1016/j.foodchem.2004.11.020

Esenwah, C.N. and Ikenebomeh, M.J. (2010). Nutritional compositions and oligosaccharide contents of preprocessed and fermented African locust beans
(Parkia biglobosa benth) seed during processing. Nigerian Food Journal, 28, 57404. https:// doi.org/10.4314/nifoj.v28i1.57404

Essack, H., Odhav, B. and Mellem, J.J. (2017). Screening of traditional South African leafy vegetables for specific anti-nutritional factors before and after processing. Food Science and Technology, 37(3) 462-471. https://doi.org/10.1590/1678$457 x .20416$

Iheke, E., Oshodi, A., Omoboye, A. and Ogunlalu, O. (2017). Effect of Fermentation on the Physicochemical Properties and Nutritionally Valuable Minerals of Locust Bean (Parkia biglobosa). American Journal of Food Technology, 12(3), 193-200. https://doi.org/10.3923/ ajft.2017.379.384

Kala, K.B. and Mohan, V.R. (2010). Anti-nutritional potential of three accessions of itching bean (Mucuna pruriens (L.) DC var. pruriens): an underutilized tribal pulse. International Journal of Food Science and Nutrition, 61(5), 497-511. https:// doi.org/10.3109/09637480903482801

Mugendi, J.B., Njagi, E.N.M., Kuria, E.N., Mwasaru, M.A., Mureithi, J.G and Apostolides, Z. (2010). Effects of processing techniques on the nutritional composition and anti-nutrient content of Mucuna Bean (Mucuna pruriens L.). African Journal of Food Science, 4(4), 156-166.

Ndidi, U.S., Ndidi, C.U, Olagunju, A. Muhammad, A., Francis G.B. and Okpe, O. (2014). Proximate, Antinutrients and Mineral Composition of Raw and Processed (Boiled and Roasted) Sphenostylis stenocarpa Seeds from Southern Kaduna, NorthWest Nigeria. International Scholarly Research Notices, 2014, $280837 . \quad$ https:// doi.org/10.1155/2014/280837

Oatway, L., Vasanthan, T. and Helm, J.H. (2001). Phytic acid. Journal of Food Review International, 17(4), 149- 431. https://doi.org/10.1081/FRI-100108531

Oghbaei, M. and Prakash, J. (2016). Effect of primary processing of cereals and legumes on its nutritional quality: A comprehensive review. Cogent Food and Agriculture, 2(1), $1136015 . \quad$ https:// doi.org/10.1080/23311932.2015.1136015

Omafuvbe, B.O., Falade, O.S., Osuntogun, B.A. and Adewusi, S.R.A. (2004). Chemical and biochemical changes in African locust bean (Partia biglobosa) and melon (Citrullus vulgaris) seeds during fermentation to condiments. Pakistan Journal of Nutrition, 3(3), 140-145. https://doi.org/10.3923/ pjn.2004.140.145

Onwurafor, E.U.1., Onweluzo, J.C. and Ezeoke, A.M. 
(2014). Effect of Fermentation Methods on Chemical and Microbial Properties of Mung Bean (Vigna radiata) Flour. Nigerian Food Journal, 32(1), 89-96. https://doi.org/10.1016/S0189-7241(15)30100-4

Tresina, S.P. and Mohan, V.R. (2013). Assessment of Nutritional and Anti-Nutritional Potential of underutilized legumes of the genus Mucuna. Tropical and Subtropical Agroecosystems, 16(2), 155-169.

Udensi, E.A. and Okorokwo, K.A. (2006). Effects of Fermentation and Germination on the Physicochemical Properties of Mucuna cochinchinensis protein isolate. Africa Journal of Biotechnology, 5, 21-22. 